\title{
Reconciling Ecological Sustainability and Human Development: Ideas for Environmental and Sustainable Development Education
}

\author{
Olalekan Elijah Ojedokun ${ }^{1}$ \\ ${ }^{1}$ Institute of Education, Obafemi Awolowo University, Ile-Ife, Nigeria \\ Correspondence: Olalekan Elijah Ojedokun, Institute of Education, Obafemi Awolowo University, Ile-Ife, \\ 220005, Nigeria. Tel: 234-80-5733-3448; 234-81-6324-7820. E-mail: oojedok@yahoo.com; \\ olalek@oauife.edu.ng
}

Received: November 13, 2013 Accepted: January 6, 2014 Online Published: March 31, 2014

doi:10.5539/ass.v10n7p119

URL: http://dx.doi.org/10.5539/ass.v10n7p119

\begin{abstract}
Given the challenges of environmental sustainability, the school teacher, especially those handling courses and subjects related to education for sustainability would need some understanding of why environmental problems persist and be able to impact same in their respective learners. The major issues that they must emphasize are problems associated with human development and global economic practices underpinned by the neoliberal economic theory. Other issues are the impact of development-oriented practices on the ecological environment and the consequences associated with the overexploitation of the earth resources which could bring irreversible devastating consequences on humanity if care is not taken. This paper thus exposes all these issues with the view to providing what could serve as ideas that that the teachers of environmental and sustainable development education could share with their learners, especially at the teacher training levels.
\end{abstract}

Keywords: reconciling, ecological sustainability, human development, environmental and sustainable development education

\section{Introduction}

\subsection{Background}

The desire to lead worthwhile lives is paramount to everybody, if what the Human Development Index is measured by is anything to go by. But free trade, motivated by neoliberalism in the spirit of globalisation had created economic inequity in the world. The sovereign existence of most nations of the world could be seen to be threatened by selfish activities of transnational corporations and the impact that their self-minded, profit-oriented businesses have done to the whole world's ecological environment. The impact appears very enormous; hence, there is a need for urgent action, if the world will not get melted up or flooded away by the ecological foot-prints of businesses and business interests in a not-too-long time. It is therefore very expedient for everybody, people, nation, corporate groups, civil society, women and youth movements, Non-Governmental Organisations and the schools to rise up to face the challenges of ecological sustainability. This is because, a failure on the part of the world will bring consequences that would not need anyone to announce that the environment holds a "weapon of mass destruction": a destruction whose toll may be so devastating, and that there may be no one to write its history.

However, deliberate attempts to inform the world, especially the future generations currently in schools call for a synthesis of ideas that could promote the understanding of the factors associated with ecological unstainability with the view to making them understand some basics of human development index. There is also the need for desirable attitude towards sustainability, and to also employ positive approaches towards sustainable management of environmental resources. This is hoped would be done in the context of Environmental and Sustainable Development (ESD) education lessons at all levels of education. The ESD teachers and the learners may therefore need some ideas to fall upon.

\subsection{Objectives of the Paper}

The school is considered a good avenue to provide excellent best practices in terms of the impartation of knowledge designed to inculcate desirable sustainability values in the learners; especially given the roles that it often plays in the exposition of the learning content of societal problems and the culture of the people.The thrust 
of this paper is therefore to provide a preview of causes of ecological unsustainability in the context of the Human Development Index (HDI), the underpinning theory, the approach to sustainability and the implications for classroom instructions.

Premised on these objectives, certain fundamental questions are inviting answers, in order to have a clear-cut understanding of the need to reconcile human development with ecological sustainability. These are:

1) what are the perspectives on human development that explain why there is the need to reconcile human desires to lead worthwhile lives with ecological sustainability?;

2) what are the current global economic practices that are observed to be threatening ecological sustainability? ;

3 ) is the neoliberal economic theory culpable for ecological unsustainability?

4) what are likely approaches towards reconciling human development with ecological sustainability?; and

5) what are classroom instructional implications of the need to reconcile human development with ecological sustainability?

\section{Perspectives on Human Development}

The concept of human development is open to many interpretations. But on a general perspective, it has to do with conditions associated with human existence; which make people under any reference to be classified as leading lives of good quality. Many authorities subscribe to this assertion. The One World - Nations Online (2009) remarks that "human development is first and foremost about allowing people to lead the kind of life they choose - and providing them with the tools and opportunities to make those choices." According to the One World - Nations Online, before a nation can be classified as wealthy, the conditions of her people in terms of being able to make rational decisions that will assure a realisation of full potential, productivity and creativity to fulfil personal interest and needs must be met. These will at the end assist in leading long and healthy lives, and enhance participation in the life of the community - as a result of access to appropriate life-supporting resources.

The United Nations Development Program - UNDP (2009) explains that people can be regarded to be benefiting from development, if they have wider options and greater opportunities for education, health care, income and employment, to mention but few. The evidences of these opportunities for successful livelihood are what the UNDP refers to as Human Development Index (HDI) which is a measure which "combines normalized measures of life expectancy, literacy, educational attainment, and GDP per capita for countries worldwide. This index is thus a major yardstick by which nations such as those in North America, Western Europe, Oceania, and Eastern Asia, are classified as developed; and others in Eastern Europe, Central and South America, South-east Asia, the Caribbean, and the oil-rich Arabian Peninsula, as developing countries.

Premised on the HDI and with particular focus on good conditions of living, human well-being has been regarded as the outcome of development according to the United Nations Environment Programme - UNEP (2008). To UNEP, human well-being can be classified according to three views, namely

- Availability of resources - such as money and other assets;

- $\quad$ Subjective views - How people feel about their lives, in terms of satisfaction derived from traditions and cultures; and

- $\quad$ Opportunities - Benefits such as proper nourishment, respect, safety and security of life and property and opportunities to participate in community life.

In the opinions of UNEP, all these three views cannot be separated from the environment: because "environment is where we live; and development is what we all do in attempting to improve our lot within the environment in which live". The UNEP asserts further that, it is the environment that contributes to development as a means to promote economic growth; individuals assess own living conditions by taking into account the intrinsic importance that environment has for life satisfaction; and that environment helps people to be what they want to be, not only generating income for them but providing multidimensional appreciable impacts.

Bearing in mind all these, it is very pertinent to ensure that the environment or the environmental system is sustained. This therefore spurs the need to take a brief look at the current global economic practice, with a view to exposing how the environmental system or ecosystem is affected by the contemporary global economy.

\section{A Brief Look at the Current Global Economic Practice}

The current global economy has been regarded as "borderless business" (Tibbett, 2002). It operates in the name of "globalisation" which permits multinational corporations to harmonize customers by opening additional markets, after having accessed raw materials, resources and investment opportunities: and selling its products 
anywhere in the World (BNET United Kingdom, 2009: Online). Hence a company can produce in one country, pay taxes in another and demand infrastructural spending in another (Beck, 1999). According to Beck,

...transnational corporations export(ed) jobs to parts of the world where labour costs are lowest. Next, computers (and with internet) enable (d) them to break down goods and services, and to produce them through a division of labour in different parts of the world, so that national and corporate labels inevitably became illusory. Then they beg(an) to play countries or individual locations against one another, in a process of global horse trading to find the cheapest fiscal conditions and the most favourable infrastructure(p.25).

This borderless trade system however appears somewhat very disgusting and may soon be things of the past if candid efforts are not made to modify it. Tibbet (2002) captures it in his own perspectives as summarised below.

According to Tibbet, globalised economy is a "game" that is played by huge transnational corporations (TNCs) because they want to dominate the world economy. They are however companies based in developed countries, trading with resources, cheap labour, land and other materials that can be sourced cheaply in the less developed countries. Although they seem to be opening up the external locations of their businesses to some degrees of development, through provision of cheap labours, the swift at which they move their businesses when the profit is no more forth coming is very alarming. Their departures often cause unemployment, economic disintegration and social unrest; and since their workers are de-unionised, even when they are cheated, they have no say. Moreover, they seem to have the gut to violate national policies and manipulate the markets, because they have the wherewithal to bribe the government and exploit tax loopholes. The problem of open monopoly of foreign direct investment drains the domestic economy of their business bases. They are thus able to repatriate huge profits to developed countries without real technology transfer: yet, local capital is reduced to subsidiary role. There seems also to be a regulatory body for transnational businesses. This is the World Trade Organisation (WTO). However, because the base and largest constituent members of the WTO are from developed countries, TNCs still have their ways to exploit the whole world to their advantages. In fact, when they have the course to vacate a place, they leave such an area worse than they have met it. Alarmingly, "TNCs' image as global employers, big investors and engines of growth is marred by association with environmental degradation, asset-stripping, workers' right abuses and corruption throughout the developing world"(Tibbet, 2002: 18-19). Some other scholars such as Khor (2001), Smyth (2003) and Marquand (2002) have near, close or similar perspectives to those of Tibbet and Beck that have been discussed here.

However, no matter what the criticism of globalised trade system may be, operators of the business have basis for their actions. The rule they operate upon is rooted in the neoliberal economic theory which is previewed below.

\section{Theory Underpinning the Threat to the Environment}

\subsection{The Neoliberal Economic Theory}

"Neoliberalism is a theory of political economic practices that proposes that human well-being can best be advanced by liberating individual entrepreneurial freedoms and skills within an institutional framework characterized by strong private property rights, free markets, and free trade" (Harvey, 2005: 2). According to Harvey, the state only has the responsibility to create and preserve the institutional framework for private enterprise and markets, and as well as guarantee the quality and integrity of money; set up the security apparatuses and the defence of the fundamental rights of the people : but will not participate in any enterprise and markets created.

Since 1946, the International Chamber of Commerce (ICC, in Paris) which is the protagonist of neo-liberalism simply advocates that markets and trade should be free. The ICC defines trade and commerce mandate as breaking down of barriers to international trade and investment so that all countries can benefit from improved living standards through increased trade and investment flows. Maiteny and Wade (2003: 65) provide a precise summary of the perspectives of neoliberal economy which now rules the world. In their comparison of neoliberalism with social democrat and Neo-Marxist driven economy, Maiteny and colleague opine that neoliberalism allows global trade to benefit all members of the society including the poor whom the trade benefits will trickle down on. According to them, development is assured when there is economic growth, via the free market which serves as the arbiter of decision making. Other perspectives are that, for poorer countries to benefit from the free trade, they must open up their markets for the world economy; barriers to tariff and protectionism should be reduced; while the national government should interfere less into businesses. Lastly, trade unionism and issues of labour rights and environmental protection should be de-emphasized, because they seem to be capable of scaling businesses down. 
While globalised trade seems to sound a good one, its critics have made it clear that it is a complete defeat of the world, especially going by the idea of deregulation. This might have informed the opinion of Hari (2002) which explains that globalisation is the offspring of neoliberal economy that fell with the collapse of the world trade centre. Hari remarks that "September 112001 attack on the US was not a death-blow...but a godsend." Hari (ibid) goes further that the idea that government of a nation should have less say about trade activities, while the protagonists of free trade are protecting their own national interests, might have as well prompted Bovis, and Monbiot (unreferenced), to criticize the WTO as having a "one size fit all" neoliberal model, which promotes protectionism, which is capable of sending wrong signals to the developing world. An organisation named "Alternative information and Development Centre" - AIDC (2003) (reported in Maiteny and Wade, 2003) and CorpWatch (2009) provide a similar report in respect of neoliberalism as put by Martinez and Garcia (2002).

The AIDC (2003) and CorpWatch (2009) provide opinions that could be regarded to be a summary of the idea of the negativity of neoliberalism. According them, neoliberalism abhors government's control of the market; advocates cut in public expenditure for social services; privatisation of government businesses through sales of state-owned enterprises, goods and services such as banks, key industries, rail road, toll highways, electricity, schools, hospitals and even fresh water to private investors. It concentrates wealth more in a few hands thereby making the public pay even more for its needs. It eliminates the concept of "the public good" or "community" and replacing it with "individual responsibility" by way of pressuring the poorest people in a society to find solutions to their lack of health care, education and social security all by themselves -- then blaming them, if they fail, as "lazy." It reduces government regulation of everything that could diminish profits, including protecting the environment and safety on the job in the name of deregulation. The rule of the market is that of "free" enterprise or private enterprise which liberates the markets from any bonds imposed by the government no matter how much social damage this causes. It affords greater openness to international trade and investment; reduces wages by de-unionizing workers and eliminating workers' rights; eliminates price controls; allows total freedom of movement for capital, goods and services. It finally blindfolds people that "an unregulated market is the best way to increase economic growth, which will ultimately benefit everyone" (Martinez \& Garcia, 2002).

\subsection{Impact of Neoliberalism on Developing Countries}

From the foregoing, it is noteworthy that third world countries are always the losers in a practical neoliberal economy and it has manifested in so many ways. This is more importantly because the transnational corporations derive many advantages in the third world - in cheap raw materials and cheap labour. Hence they leave developing areas worse than they met them. By this they finally create dependency. Peet (1991), in his article on "dependency and world systems theories" informs that in dependency the centre (developed countries) and the periphery (underdeveloped countries) become increasingly polarised as capitalism develops the one and under-develops the other in a single historical process. Some other issues informed from Peet (ibid) are that development and underdevelopment are interdependent structures within the global economic system. The dominant achieves self-sustaining growth while the dependent can grow as a reflection of the dominant countries. The economic position skewed the periphery's social structure, so that local power was held by a small ruling class who use the gains from exporting luxury consumption rather than investment. Real power is wielded from external poles of command in the dominant metropolitan countries. Underdevelopment is generated by the same process which develops the centre; in particular, underdevelopment in the periphery results from the loss of surplus which is expropriated for investment in the centre (Peet, 1991: 130-136).

By implication, a lot of dependency burden is put on the developing countries especially following borrowing of loans from the Washington consensus - the World Bank and the International Monetary Fund (IMF). These financial institutions impose policy restrictions and dictate what to use the loans for. Critical examples are the Structural Adjustment Programmes (SAP) that were applied all across the world, especially in Africa in the 1980s. The messages and practices of SAP are basically focused on structural adjustment which advocates stabilisation and structural change (Maiteny \&Wade, 2003: 52). According to Maiteny and Wade, the IMF manages stabilisation of short-run policies whose objectives are to reduce inflation and to stabilize inflation. While the duo of IMF and World Bank manages structural change: a medium-term strategy, meant to ensuring economies was returned to economic growth (Maiteny \& Wade, 2003: 52).

Regrettably, developing countries find it difficult to repay the loan taken from these organisations, as their currencies have been devalued and increasing loss of job and low standard of living erupt : with attendant consequences such as civil unrest, outbreak of epidemic, and even death; increase in crime wave and above all environmental degradation associated with urbanisation. This could have been caused by people who have migrated into the urban centres in search of improved means of livelihood; and cannot easily go back to their bases because of lack of expectation. But they have to struggle to cope with finding means of livelihood and 
other attendant issues of waste and sewage disposal, coupled with generation of carbon dioxide, which is now the talk of world in the context of climate change (The Economist, January, 2009: 56-58).

It therefore suffices to say that globalisation and neoliberalism are aimed at development, but on the long run put a national government out of control. But the fact speaks for itself i.e. advocates of neoliberalism are profit-minded. They depend on the developing areas in what may be regarded as "robbing Peter to pay Paul." This happens because, development was not their main objective, but profits: whereas a genuine development should look at other worlds in terms of what they lack (and to provide it) (Sachs, 1992). But the current global free trade did not provide that. As a result of its external trade liberalisation, there have been side effects, such as de-industrialisation, which renders many industrial sectors and industrial enterprises of most developing countries more unviable. The resultant effect is the dumping of cheap and second-hand clothes, shoes and cream etc. in them (Khor, 2001). In the opinions of Sachs (ibid), the development race was fought unfairly and had led nations to the abyss of unemployment , injustice (including violation of rights of women and children), poverty, and the worst of all, the environment was turned into a problem that became the object of special strategies. This is because the soil, water and air have been poisoned, as industries have created the problem of greenhouse effects: now posing fundamental threats to human existence. The Royal Dutch Shell Petroleum oil pollution in the Niger Delta in Nigeria is a typical example.

Similarly, external trade liberalisation (in the opinion of the authors) is a contemporary slave trade, now operating as free enterprises; which may not be clearly differentiated from the early scramble for and partition of the world that created third world countries, as put by Ponting (1991). According to Ponting, slave trade, religion, technical advancement and quest for raw materials for emerging industries, resulted into breaking empires and kingdom which would have naturally evolved and developed on their own: but now as dependent territories, called developing, underdeveloped or third world countries. In fact, Ponting makes us to realise that all these factors, put together, commenced the environmental degradation process, in Africa, Asia, Caribbean and Latin America, for example. The environmental damages that have been done in the name of development are a result of the clearing of forest for sugar cane production and animal husbandry, mining of solid phosphate for fertiliser production, the introduction of exotic crop species and mono-cropping, the introduction of cash crops, application of fertiliser, technology-induced farming, specialised trading (e.g. of sandal wood in the Pacific Island),and mining activities of gold and iron ore etc. have contributed not only to underdevelop the now very poor countries, but have degraded the environment (Ponting, 1991: 22-36), now tending to the point of no repair.

The World Bank has added some more observations on areas where the ecosystem has been unbalanced. These include sea pollution from empty tanker-ships emptying their still-oily tanks with water for ballast and discharging the polluted mix, industrial effluents into the air and waste which end on land and water ways causing soil pollution and loss of aquatic lives. The introduction of new crops causing pest invasions, agricultural deforestation, ranching and animal grazing, bush burning which destroys top soil and render land infertile for agricultural purposes; and poaching and overfishing, urbanisation and its waste/sewage disposal and generation of $\mathrm{CO}_{2}$ from industrial development and choking of space which generates heat adding to the global carbon foot print, capable of depleting the ozone layer. Above all, war fought over natural resources and other reasons, such as those in Iraq, Kuwait, Afghanistan, Sudan, Congo, Palestine etc. which generate not only heat, but a release of toxic substances such as sulphur dioxide into the atmosphere. Dreadfully, they all cause loss of biodiversity and climate change (World Bank, 2003: 85-96).

\section{How to Reconcile Human Development with Ecological Sustainability}

A complete ecosystem is assumed to be the one that will regulate itself if it were not altered - if the Gaia hypothesis/theory/perspective is anything to go by. This is because the biosphere is an active adaptive control system able to maintain the earth in homoeostatic (Lovelock, 2002). But has the deed not been done? The ecosystem had been altered and the environment is now in conflict with development. The end of the conflict is not sight. But the war is still relatively cold. Hence people with concerns on the environment should quickly "mediate" and perhaps reconcile the conflict. Otherwise, the "arm race of USSR may not be able to withstand the tact with which the "US" will beat its ideology hands down and collapse its empire." By this analogy, the author symbolises development with USSR and environment USA. Paradoxically, development is capitalistic (USA -neoliberalism) and environment enjoys some degree of communism (USSR -Socialism/Marxism). Notwithstanding the whole world may not be able to bear the cost of the collapse, or on the other hand the "strike / raid /invasion" of the "US" in question here, environment, if specialised strategies (Sachs, 2002) do not "stand up" quickly in all honest and sincerity of purposes to "dialogue."

Indeed, going by all the significant impacts that free trade had created in the name of development, it is 
important to seek alternative to neoliberalism; and as this is sought, the environment should be put in mind. For example, if social-democrats will advocate state control of the economy so that national economic gains can trickle down the poor (because neoliberalism had that deceitful intention and failed gallantly), there will be the need to harness the resources of the environment whose ecological systems have already been badly altered through previous development efforts. Hence there is the need to delink from the global economy. There is the urgent need for global democracy, partnership between business, civil society and the state; appropriate intervention in order to mediate the worst effect of free market, and to make poorer countries to benefit from opening their economies to the world market (Maiteny \& Wade, 2003: 65).

By and large, the whole discourse has been on sustainability; and the most pressing global issue is the reconciliation of ecology with issues that are associated with development. This may be because as development requires the environment to grow, so also is the environment raising an alarm on its current status, which not only capable of eroding resources of the water, land and air, but human beings and all the arts and artefacts infrastructures, that have been created by development with resources harvested from the environment. Therefore, bearing in mind all the impacts and the irreversibility of some of the impacts, and of the probability of homoeostatic actions of the ecosystem it is pertinent that some mitigation measures have to be put in place. This is because no one knows when "Gaia" will rebalance itself - whether in the next decade, century or millennium. Perhaps, (probably) the remaining undisturbed or partially disturbed ecosphere will be able to or not sustain itself and sustain humanity, which is its component part - human beings being part of the ecosystem, and as children that nature nurtures as a mother, and as sisters to grow along together (Sahtouris, 1999). This is the ecofeminist's perspective of the earth as a sibling of the same parent with human beings (Mellor, 1997). The mitigation measures may probably keep sustaining life of the present generation and keep hope alive for the next generation of human to find their means of livelihood without too much stress.

To keep on sustaining life of the present generation and keeping hope alive for the next generation of human-kind to find their means of livelihood, without too much stress, is the global definition of sustainable development(SD) (Johnson,1994). Thus development should mind this "catechistically". But the environment will be the sole determinant, because all resources attached to comfortable human development (using UNDP: HDI) are tapped from the environment. Specifically, development should have human face - "because human beings are at the centre of concerns for (SD). They are entitled to healthy and productive life "in harmony with nature"' (Rio Principle 1) .Hence, the Rio Declaration on Environment and Development (1992) must be adhered to "catechistically". Principle 4 of the declaration principally gives significant recognition to the environment. It states,

in order to achieve sustainable development, environmental protection shall (must) constitute an integral part of the development process and cannot be considered in isolation from it (Johnson, 1994: p.20.)

Other 25 principles (2-3 and 5-27) provide real alternatives to neoliberalisation as if the Rio conference were predicting the evil that globalisation and its twain, free trade, will bring on nation states and the environment: in that it has nurtured underdevelopment and caused ecological imbalance. A summary of the positions of the principles as put by Johnson are paraphrased viz:

- Nation states are sovereign and have the fundamental rights that can be fulfilled to exploit their own resources pursuant to their own environmental and development policies in accordance with meeting the future needs of their citizens (2-3)

- There should be interstate cooperation to decrease poverty and help environmentally vulnerable states(5\&6)

- Cooperation in a spirit of global partnership to conserve, protect and restore the health integrity of the ecosystem; as states reduce and eliminate unsustainable patterns of production and consumption....(7\&8)

- Cooperation among states to strengthen endogenous capacity building and participation by local citizens in handling environmental issues $(9 \& 10)$

- Enactment of environmental standards of management that will not accrue cost to other countries; while trade policy measures for environmental purposes should not constitute disguised international trade (11\&12)

- State should have laws regarding liability and compensation for victims of environmental damage; while trans-border deposit of harmful wastes should be disallowed (13\&14)

- Lack of scientific certainty should not be excuse for postponing cost-effective measures to prevent environmental degradation; while environmental costs should be borne by the polluter (15\&16) 
- $\quad$ Environmental impact assessment must be conducted before any serious project; while notice disasters should be given to neighbouring state and to assist victims (17\&18)

- $\quad$ Prior notice of potential environmental emergencies should be given to neighbouring states (19)

- Youth and women must be given adequate education and involvement in environment and development issue (20\&21)

- Indigenous people must be recognised and supported to enable them to participate in environmental and development issues (22)

- $\quad$ "Environment and natural resources of people under oppression, domination and occupation should be protected" (23)

- International laws guiding warfare must be abided with because war causes retrogression of development; hence peace and dialogue should be embraced (24,25\&26); and finally

- $\quad$ States and people(should) cooperate in good faith and in a spirit of partnership in the fulfilment of the principle embodied in (the) Declaration and in further development of international law in the field of sustainable development(27)(Johnson:1994)

Going by the Rio declaration, the state is expected to wield absolute powers over her economic and development terms; rather than conceding her economic sovereignty to transnational corporations. The emphasis then should have been on cooperation and interdependence, which is the last item in the Rio principles:

States and people (should) cooperate in good faith and in a spirit of partnership in the fulfilment of the principle embodied in (the) Declaration and in further development of international law in the field of sustainable development (27).

Had all the principle been followed to the letters and in adherence to the UN Charter for Global Democracy (Henderson, 1999), the author is of the opinion that the current global economic recession would not have surfaced. Any way it is evident that the global "economic might" is falling, and no one knows where the direction of development will go. But this author thinks that nature will not operate in a vacuum. Development may go anywhere, but it must be ecologically sustainable.

Lastly, the Rio principles are general terms. There are some that are practically specific. They have to do with economy in practise vis-a-vis the impact of the free trade enterprise on the environment. They are options that concern the damages that have been done by neoliberal economy, especially in relation to the developing world. A cursory look at some opinions on mitigating measures to the impact of ecological foot prints of development recently witnessed around the world and as reactions to environmental problems listed above could drop some suggestions that globalisation must be regulated, so that the world's wealth will spread equally; and trade should not be too profit-oriented to the extent of sacrificing the environment. (Tibbet, 2002). Businesses should be more accountable for social and environmental impacts of its activities (Coles \& Murphy, 1999). There should be fair pricing of farm produce, and concern for the farms where the produces are derived (Garstang, 2002-2003). The rules of the World Trade Organisation should be reviewed because it allows protectionism, which in turn impacts on developing countries, and whose citizens take solace in damaging the environment to seek means of livelihood, out of nothing (Khor, 2001). There should be cut in military spending, because it is an unprofitable venture, especially if the war to be fought is for selfish economic reasons or personal aggrandisement - Bills for such should not be passed in congress. (Marquand, 2002). There should be performance reporting to curb intentional pollution of land, water and air; and there should be global alliance in support of sustainable biodiversity which should be encouraged and funded (World Bank, 2002). Collective use of sweat labour that will assure ecological sustainability must be encouraged; while rural areas should be well catered for in terms of social services, so that emigration that takes its toll on the urban areas in congestion and pollution is reduced (Pepper, 1996). Efficient environmental laws have to be put in place. There should be no sacred cow. The polluter must pay for pollution and also pay for uncertainty as well (Constansa, Dally \& Bartholomew, 1992). There should be good agricultural practice, reinforcing the traditional shifting cultivation and the use of organic fertiliser (New Scientist, 2001). Exotic species should not be introduced in the name of agricultural businesses, because they cause pest infestation (Sahtouris, 1999). There should be adequate population and birth control to check excessive population increase because it impacts greatly on the environment (Naess, 1990). There should be ecological justice - people from where raw materials are tapped must be well catered for. This will forestall arm-conflicts (Naess, 1990). There should be debt for nature swap, to encourage nations whose environment need urgent attention. The loans that such nations have borrowed can be cancelled with conditions that they will improve their environment and conserve biodiversity (Maiteny \& Wade, 2003). Lastly, education that caters for 
awareness, knowledge, attitude, skills and community participation should be encouraged and funded. Such education must be value-laden, relevant to learners experience; and clearly communicated with discovery learning, will be most enduring and sustainable (Maiteny, 2000).

\section{Conclusion and Implications for Classroom Instructions}

From the foregoing, it is noticeable that human development is at a serious hot and cold war with ecological sustainability. The teachers of environmental and sustainable development (ESD) education have a crucial role to play in their reconciliation. If the opinion of Maiteny and Wade (2003) above is anything to go by, environmental and sustainable development education teachers must provide content detailed and accurate education that will facilitate useful awareness, and acquisition of appropriate knowledge, attitude, skills and sense of community participation among members of the human community. Some of the content that are useful are those related to the issues of globalisation, free trade associated with neoliberalism, the provisions contained in the Rio Declaration, the Human Development Index as provided by UNDP, and a host of other relevant facts. It is hoped that teachers of ESD will find these concepts and ideas very useful in their preparation of lesson plans and the notes that learners will be made to copy for their own private reading. These are all meant to achieve the overall objectives of environmental and sustainable development education at a global scale.

\section{References}

Beck, U. (1999). NS Essay: Beyond the Nation State. In Unit 5 Reader: Theories and Perspectives in Environment and Development (pp. 58-61). London: Distance Learning Centre, London South Bank University.

BNET United Kingdom. (2003). BNET Business Dictionary - Business Definition for: Globalization. Retrieved from http://dictionary.bnet.com/definition/Globalization.html

Coles, D., \& Murphy, K. (1999). Social accountability: A new approach to business. In Unit 5 Reader:Theories and Perspectives in Environment and Development (pp. 58-61). London,London:Distance Learning Centre, London South Bank University.

Constansa,R., Dally, H. E., \& Bartholomew, J. A. (1992). Goals, agenda, and policy recommendations for ecological economics. In Unit 5 Reader: Theories and Perspectives in Environment and Development (pp. 167). London: Distance Learning Centre, London South Bank University.

Corp Watch. (2009). What is Neoliberalism? A Brief Definition for Activists: By Elizabeth Martinez and Arnoldo Garcia. Retrieved March 1, 2009, from http://www.corpwatch.org

Ellis, E. (2008). Ecosystem. In J. E. Duffy \& C. J. Cleveland (Eds.), Encyclopedia of Earth. Washington, D.C.: Environmental Information Coalition, National Council for Science and the Environment. Retrieved March 2, 2009 from http://www.eoearth.org/article/Ecosystem

Environmental Society of Oman. (2009). Components. Retrieved March 2, 2009, from http://www.environment.org.om/components.php

Hari, J. (2002). Whatever happened to No Logo? In Unit 5 Reader: Theories and Perspectives in Environment and Development (pp. 117-119). London: Distance Learning Centre, London South Bank University.

Harvey, D. (2005). A brief history of neoliberalism. New York: Oxford University Press.

Henderson, H. (1999). Chart 1 The United Nations sytem' and Chart 2 The charter for global democracy:12 areas of urgent action. In Unit 5 Reader: Theories and Perspectives in Environment and Development (pp. 53-55). London: Distance Learning Centre,London South Bank University.

Johnson, S. P. (1994). The Rio declaration on environment and development' Exract from the Earth Summit. In Unit 5 Reader: Theories and Perspectives in Environment and Development (pp. 20-21). London: Distance Learning Centre, London South Bank University.

Khor, M. (2001). Present problems and future shape of WTO and the multilateral trading system. In Unit 5 Reader: Theories and Perspectives in Environment and Development (p. 67). London: Distance Learning Centre, London South Bank University.

Kirchner, J. (2002, March). The Gaia Hypothesis: Fact, Theory, and Wishful Thinking.

Lazarus, N. (1998-1999). Charting globalisation. In Unit 5 Reader: Theories and Perspectives in Environment and Development (pp. 111-116). London: Distance Learning Centre, London South Bank University. 
Lovelock, J. (2002). Science. In Unit 5 Reader: Theories and Perspectives in Environment and Development (p. 179). London: Distance Learning Centre, London South Bank University.

Lovelock, J. (2002, March/April). What is Gaia? Resurgence, 211, 7-8.

Maiteny, P. (2000). Values,spirituality and education for sustainable development. In Unit 5 Reader: Theories and Perspectives in Environment and Development (p. 192). London: Distance Learning Centre, London South Bank University.

Maiteny, P., \& Wade, R. (2003) Unit 5 Guide: Theories and Perspectives in Environment and Development. London: Distance Learning Centre,London South Bank University.

Marquand, D. (2002). The playground bully. In Unit 5 Reader: Theories and Perspectives in Environment and Development (pp. 75-78). London: Distance Learning Centre, London South Bank University.

Martinez, A., \& Arnoldo, G. (2002) What is neoliberalism? A brief definition for activists. In Unit 5 Guide: Theories and Perspectives in Environment and Development (p. 39). London: Distance Learning Centre,London South Bank University.

Mellor,M. (1997). Ecofeminist thought. In Unit 5 Reader: Theories and Perspectives in Environment and Development (pp. 146-150). London: Distance Learning Centre, London South Bank University.

Naess,A. (1990). Sustainble development and deep ecology. In Unit 5 Reader: Theories and Perspectives in Environment and Development (pp. 186-191). London: Distance Learning Centre, London South Bank University.

New Scientist. (2001). An ordinary miracle. In Unit 5 Reader: Theories and Perspectives in Environment and Developmen (p. 177). London: Distance Learning Centre, London South Bank University.

One World - Nations Online. (2009). Human Development. Retrieved March 2, 2009, from http://www.nationsonline.org/human_development_low.htm

Peet, R. (1991). Dependency and world system theories. In Unit 5 Reader: Theories and Perspectives in Environment and Development (pp. 130-136). London: Distance Learning Centre, London South Bank University.

Pepper, D. (1996). Radical Materialism. In Unit 5 Reader: Theories and Perspectives in Environment and Development (pp. 164-166). London: Distance Learning Centre, London South Bank University.

Ponting, C. (1991). Creating the Third World'. Extract from A Green History of the World. In Unit 5 Reader: Theories and Perspectives in Environment and Development (pp. 22-36). London: Distance Learning Centre, London South Bank University.

Sachs,W. (1992). Development: A guide to ruin. In Unit 1 Reader:Introduction to Environment and Development Education (pp. 110). London: Distance Learning Centre, London South Bank University.

Sahtouris, E. (1999). A matter of maturation. In Unit 5 Reader: Theories and Perspectives in Environment and Development (pp. 181-185). London: Distance Learning Centre, London South Bank University.

Smyth, A. (2003). New York, London, Paris...Garstang. In Unit 5 Reader: Theories and Perspectives in Environment and Development (p. 64). London: Distance Learning Centre, London South Bank University.

The Economist. (2009, January). The people crunch. pp. 56-58.

Tibbett, S. (2002). Borderless business :transnationals and the world economy. In Unit 5 Reader: Theories and Perspectives in Environment and Development (p. 62). London: Distance Learning Centre, London South Bank University.

UNEP. (2008). Global environment outlook-GEO4. Nairobi: UNEP. p.6

United Nations Development Programme - Human Development Report Office. (2009). Human Development Reports (2009-2010). New York: Oxford University Press.

World Bank. (2003). 'Making market work for the poor' Extract from the World Development Report 2000/2001: Attacking Poverty. In Unit 5 Reader: Theories and Perspectives in Environment and Development (pp. 85-96). London: Distance Learning Centre, London South Bank University. 


\section{Copyrights}

Copyright for this article is retained by the author(s), with first publication rights granted to the journal.

This is an open-access article distributed under the terms and conditions of the Creative Commons Attribution license (http://creativecommons.org/licenses/by/3.0/). 